\section{Class, Gender, Pleasure, and Criticism}

To the Editor:

Richard Levin's "The Poetics and Politics of Bardicide" (105 [1990]: 491-504) makes wicked fun of what this reader-response critic terms the text-active position. Levin points out the absurdities of critics' claims to the "real meaning" of a text. He shows the pretentiousness of the pretense to an absolute, god's-eye view of what a text does or is. He punctures the claim that we can step out of the mortal psychological processes of perception and interpretation that necessarily produce any critic's reading. Levin targets those who premise The Death of the Author and substitute an active, projecting, strategizing, revealing, concealing text for the lost bard. I think he makes it clear, however, that the same anomalies and pretensions appear when more traditional critics claim "objective knowledge of the real meaning of a text" (499).

Levin's critique thus calls down-I hesitate to say it-a Shakespearean plague on both houses. He leaves us with the ever-daunting question, Where do we go from here?

I suggest that the beginning of wisdom is frankly to acknowledge a different "project of the text." The real purpose of all these readings, formalist-humanist or anti-formalist-humanist, is that their authors may publish and not perish. (From this point of view, Levin might note, the authors he cites are very much in existence, indeed somewhat frantically so.) We can begin by granting that the primary aim of literary criticism as we know it today is publication and all the rewards that publication brings.

If so, then what might we publish if we were to give up our claims to superhuman objectivity? We would, of course, have to acknowledge our own activity in our criticism, but greater critics than we have done so. Indeed it was customary until recent decades. We might, for example, express opinions. We might point to things to admire or condemn. We might conduct a dialogue with a text. We might parody, we might contest the text, or we might engage the author in a conversation as some historians today engage their subjects. In short, we might try for a little more imagination in our publishing than either the old or the new New Critics show. Levin's witty exposé points, if not the only way, one way.

NORMAN N. HOLLAND University of Florida
To the Editor:

By using their own words, for the most part, Richard Levin clearly shows us how neo-Marxist and feminist Freudian critics have reduced Shakespeare's plays to parables of the consequences of domination by a class or a gender. For these critics, every one of Shakespeare's plays, no matter how diverse the surface action, conceals the same economic or social conflict. They contend that "no matter how 'silent' the text may be about elements of this conflict, it must really contain them" (499). Nor is the conclusion in any play a real resolution of these conflicts; it is merely an attempt to rationalize the patriarchal or upper-class values: " $[\mathrm{N}]$ o matter how satisfactory the resolution may appear, it must really be 'imaginary' because the contradictions it seems to resolve are by definition unresolvable . . ." (499).

But as successful as he is in pointing out the absurd lengths to which neo-Marxist and neo-Freudian critics go to reach their conclusions, Levin is less successful, it seems to me, when he explains just what causes these critics to arrive at such absurd conclusions. For Levin, the cause is The Death of the Author. Bypassing the author allows critics to find in every play their own ideas rather than Shakespeare's and to judge the success of a play by how clearly it demonstrates their own values. To avoid such solipsistic criticism, we should, Levin concludes, repudiate not only the particular biases of these neo-Marxists and feminist Freudians but also the concepts of the intentional fallacy and irony associated with the New Critics of a previous generation, and we should adopt in their place the kind of interpretation that would be limited to the author's intentions.

Levin's mistake is the obvious one of not questioning the assumptions that the meaning of a literary work is the reflection of the author's intentions, that we can discover these intentions, and that no matter how much an interpretation might increase our understanding and enjoyment of a work (and even if it came from the pen of a brilliant critic such as Coleridge, Bradley, Knight, or Frye) the interpretation can only be justified by evidence that Shakespeare wanted us to see it. But what is more important in this context, although not as obvious, is that Levin's focus on the intention of the author, as well as his distrust of ironic meanings, prevents him from recognizing the real source of the absurd conclusions of the neo-Marxist and feminist interpretations-namely, their failure to distinguish what happens on the stage from the real event. The fons et origo malorum, what allows criticism to see failure (particularly in the conclusions) in plays that most readers find to be among the greatest works ever written, is that politicized (or moralized) criticism does not 
recognize the autonomy of the literary experience.

Levin gets very close to noting this weakness when he points out how suspicious these critics are of pleasure. He cites one author who wants us to deny the "aesthetic satisfaction" in King Lear because if we allow ourselves to enjoy the play, we would be endorsing its "ideological position" (503n13) - and the play's position is, of course, not in accord with the critic's values. Levin is equally caustic of those who argue that there can be no resolution in Othello as long as the play does not resolve "the same impotent dialectic of [male] violence . . . that caused its rupture" or in Macbeth "so long as the . . . ideology of restoration prevails" (qtd. on 496). But when considering just why critics who certainly show evidence of a literary sensitivity far above that of the average reader nevertheless seem to derive little pleasure from the plays, Levin merely repeats the critics' viewpoint: " $[P]$ leasure is seen as a kind of bait offered by the text . . . to make us complicit in its ideological project" (496).

But to see the play as an "ideological project" has nothing to do with The Death of the Author but stems from the tendency of some critics, from Plato through Tolstoy to those of the present day, to see art only as an instrument for the inculcation of religious, political, or moral values and feelings. And to the extent that these neo-Marxist and feminist Freudian critics follow this tradition and so refuse to find at least some delight in literature that may "shock the virtuous Philosopher" (whether the virture is Christian, feminist, revolutionary, or conservative), their writing will lead to the absurd conclusions cited by Levin. Until we realize that the problem is not the displacement of the author by the text but rather the idea of literature as instrumental rather than autonomous, we will not be able to go forward with the kind of criticism that deepens our understanding and enhances our enjoyment of Shakespeare's plays.

\section{LAWRENCE HYMAN Brooklyn College}

City University of New York

\section{To the Editor:}

The reappearance in PMLA of Richard Levin's bashing of the new historicism will no doubt be the occasion for another round of outraged protest (see "Feminist Thematics and Shakespearean Tragedy," 103 [1988]: 125-38; Forum, 103 [1988]: 817-19, 104 [1989]: 77-79). Before Levin's defenders once more claim the moral high ground of the oppressed minority struggling for freedom of speech against a fantasized hegemony of the left, let me try to clarify why the response to Levin's essays is so much more heated than any response to Edward Pechter's critique of the new historicism in these same pages ("The New Historicism and Its Discontents: Politicizing Renaissance Drama," 102 [1987]: 292-303).

I will focus on one characteristic passage in Levin's essay:

One does not ask how or why the text gave itself, or was given, this project-that is treated as a donnée. The project is always bad since it involves the reproduction or reaffirmation of some aspect of the oppressive and deceptive ideology (in the Marxist sense of "false consciousness") that dominated the Renaissance world. . . .

The first sentence implies that the assumption that the text is carrying out an ideological project is of some mysterious origin. The second sentence at least partly dispels the mystery; Marxist literary critics follow Marx's critique of the social formation of consciousness, in which one's beliefs reflect one's place in a particular class and in which the dominant ideas of a society are a veiled representation of the interests of the ruling class. Marxist critics do in fact ask how and why texts carry out the work of ideological mystification, and there is a clear continuity from the theoretical formulations of Marx and Marxist theorists on this issue to the use of those ideas in Marxist literary criticism.

One might wish to question whether Marxist principles are sometimes applied to literary analysis in an overly positivistic fashion, and that critique could be carried out at both the theoretical and the practical levels. That is what Pechter does, but that is not what Levin does. Levin takes gratuitous potshots ("One does not ask . . .") that he should know are wrong. The connection between the first and the second sentences from Levin that I have quoted is loose enough to allow two possible interpretations of Levin's misrepresentation of the grounds of Marxist literary criticism. Either Levin, in order to launch some gratuitous sarcasm, suppresses his knowledge of a theoretical basis for assuming that a text is doing the work of ideology or else he simply did not do any reading into the theoretical backgrounds of Marxist criticism before he set out to prove its errors. If his reading in the subject is insufficient, I would suggest that he begin with The German Ideology.

The opposition to Levin's appearance (and reappearance) in $P M L A$ does not proceed from an intolerance for contrary viewpoints. It arises from the sense that his essays are critical gossip and not serious scholarship. It is difficult to believe that anyone's intellectual 